\author{
Al-wardah: Jurnal Kajian Perempuan, Gender dan Agama \\ Volume : 13 No 1. Edisi Juni 2019 \\ ISSN: 1907-2740, E-ISSN: 2613-9367 \\ DOI: $10.46339 /$ al-wardah.v13i1.157
}

\title{
DINAMIKA HIDUP SINGLE MOTHER (Perspektif Qashash Alqur'an)
}

\author{
Muhammad Amri \\ IAIN Ternate, Indonesia \\ (amrimarniujung@iain-ternate.ac.id)
}

\begin{abstract}
Abstrak
Alqur'an kitab suci yang diturunkan Allah swt. melalui Nabi Muhammad saw. sebagai petunjuk bagi umat manusia.. Satu fenomena kehidupan, adanya single mother berusaha menopang kelanjutan hidup memelihara anak serta keluarga dalam waktu yang sama. Ketika Alqur'an menyinggung serangkaian kisah-kisah masa lalu dengan latar belakang manusia. Studi ini merupakan penelitian pustaka dengan metode deskriptif kualitatif. Pendekatan yang digunakan adalah tinjauan Qashash Alqur'an. Penelusuran ini menghasilkan sebuah gambaran bahwa potret single mother dalam rangkaian qashash Alqur'an tercermin pada tiga kisah yaitu Maryam Ibu Nabi Isa as. pada QS. Maryam \{19\} : 16-25., Ibu Nabi Musa as. pada QS. Al-Qashash \{26\} : 7-13, dan Hajar Ibu Nabi Ismail as. pada QS. Ibrahim \{14\} : 37-38. Ragam dinamika hidup single mother dapat disarikan dari kisah terangkum dalam tiga poin : pertama, rentan terhadap stigma buruk masyarakat; kedua, terjepit dalam kondisi yang buruk; dan ketiga, memendam masalah dan menanggung beban sendiri.
\end{abstract}

Kata kunci : single mother, qashash alqur'an, dinamika hidup

\begin{abstract}
Abstrac
The Holy Qur'an was revealed by Allah through the Prophet Muhammad. instructions for humanity ... the phenomenon of life, the existence of a single mother. When the Qur'an alludes to past stories with a human background. The approach used is a review of the Qur'an Qashash. This search produced a description that the portrait of a single mother in the Qur'anic qashash series is reflected in three stories, namely Mary the Mother of the Prophet Isa as. in QS. Maryam \{19\}: 16-25., Mother of the Prophet Musa as. in QS. AlQashash \{26\}: 7-13, and Hajar Mother Prophet Ismail as. in QS. Ibrahim \{14\}: 37-38. The various dynamics of the life of a single mother can be extracted from the story summarized
\end{abstract}


in three points: first, vulnerable to the bad stigma of society; second, pinched in poor conditions; and third, harboring problems and bearing the burden yourself.

Keywords: single mother, qashash alqur'an, life dynamic

\section{A. Pendahuluan}

Kedudukan orang tua dalam keluarga merupakan komponen utama. Tidak jarang Allah swt. memposisikan orang tua dalam posisi berikut setelah posisi Tuhan sendiri. Peran yang diemban setiap suami dan istri laiknya dua sisi yang saling melengkapi. Keberadaan keduanya menjadi pilar utama yang tidak bisa digantikan sama sekali.

Realita kehidupan umat manusia tidak selalu berjalan mulus, riak-riak kehidupan senantiasa muncul mewarnai. Satu dari sekian riak tersebut adalah jatah usia yang beragam bagi setiap manusia, seringkali pasangan utuh yang terdiri dari suami dan isri ataubapak dan ibu sewaktu-waktu harus berkurang lantaran batas usia salah satu dari keduanya, perceraian di tengah jalan, ataupun lantaran ditinggal pergi dalam tempo yang cukup lama.

Sejalan dengan Firman Allah swt. dalam QS. Al-Baqarah $\{2\}: 155$

$$
\text { ر الصَّابرينَ }
$$

Terjemahnya : Dan Kami pasti akan menguji kamu dengan sedikit ketakutan, kelaparan, kekurangan harta, jiwa, dan buah-buahan. Dan sampaikanlah kabar gembira kepada orang-orang yang sabar.

Allah swt. menggariskan cobaan hidup sebagai keniscayaan yang akan dihadapi silih berganti. Diantara cobaan tersebut adalah berkurangnya anggota keluarga terdekat yang dimiliki. Sikap terbaik dalam menghadapi segala cobaan tersebut adalah menerimanya dengan penuh kesabaran. Sedih bukanlah aib yang tercela, melainkan perlu dibarengi dengan kesabaran yang tinggi.

Kenyataan ini kadang membawa dampak luar biasa bagi pihak keluarga yang ditinggalkan. Terutama bagi pasangan hidup yang selanjutnya harus melalui sisa kehidupan dengan label single parent. Beban akan lebih berat dalam kondisi seorang istri yang 
ditinggal suami, mengharuskannya mampu melewati hari-hari dengan peran dan fungsi ganda.Meneruskan roda penopang keluarga agar bisa tetap berjalan stabil sekaligus mendidik dan membesarkan anak seorang diri.

Single mother secara pribadi dan keluarga yang diembannya, menjadi satu perhatian lembaga yang bergerak sebagai pemerhati perempuan dan anak. Hal ini, lantaran rawannya keluarga semacam ini menjadi objek tertindas ataupun terintimidasi oleh pihak-pihak yang tidak bertanggungjawab lantaran minimnya power yang dimiliki secara sosial. Dapat juga menjadi pihak yang terlantarkan hak-haknya karena tidak ada sosok suami yang mengayominya secara khusus.

Alqur'an adalah kitab suci yang diturunkan oleh Allah swt. sebagai petunjuk bagi umat manusia. Segala problem umat manusia, sedianya mendapatkan perhatian oleh ayatayat Allah swt.. Meskipun penting untuk dipahami bahwa, Alqur'an bukanlah kumpulan ensiklopedi kehidupan yang mencakup seluruh lini kehidupan secara detail.

Salah satu bentuk paparan Alqur'an yang banyak diambil menjadi pelajaran hidup adalah rentetan kisah-kisah masa lalu dari para Nabi dan kaum terdahulu. Kehidupan para Nabi yang telah di utus oleh Allah swt., laiknya kepingan-kepingan potret kehidupan yang saling melengkapi satu dengan yang lainnya. Latar belakang para Nabi yang bermacammacam, menghadapi karakter kaum yang berbeda-beda menjadi cermin yang dapat memantulkan aneka hikmah dan pembelajaran mendalam bagi generasi berikutnya.

Hampir seluruh jenis latar belakang yang dimiliki manusia secara umum telah tercermin dalam latar belakang Nabi dan Rasul Allah swt.. Manusia dengan latar belakang raja dan kaya terlihat dalam sosok Nabi Sulaiman as., latar belakang yatim tercermin pada diri Rasulullah Muhammad saw., latar belakang berkecukupan kemudian tiba-tiba jatuh miskin lantaran penyakit yang sangat menjijikkan dimata manusia diwakili oleh Nabi Ayyub as., dan lain sebagainya. 
Berdasarkan poin-poin pikiran di atas, mencuat sebuah pertanyaan mendasar. Sejauh manakah perhatian Alqur'an menyorot fenomena kehidupan single mother, lebih spesifik dalam uraian qashash Alqur'an (kisah-kisah Alqur'an). Sebagai sebuah paparan yang lebih dekat dan mudah untuk dicerna dan diserap pesan dan makna di dalamnya.

\section{B. Pembahasan}

\section{a. Makna Single Motherdan Qashash Alqur'an}

Pada dasarnya ada dua istilah yang berdekatan satu sama lain yaitu single parent dan single mother. Single parent adalah kondisi dimana orang tua (ayah atau ibu) mengasuh anak mereka sendiri tanpa pasangan. Adapun single mother adalah wanita yang ditinggalkan suami atau pasangan hidupnya baik karena terpisah, bercerai, atau meninggal dunia untuk kemudian memutuskan melanjutkan kehidupan dengan jerih payah sendiri.

Sejatinya, pada setiap manusia yang dilahirkan hanya memiliki satu orang Ibu atau single mother dalam makna leksikal kebahasaan. Namun, kemudian pemaknaanistilahi-nya mengerucut kepada sosok Ibu yang melalui kehidupan mengurus rumah tangga dan memelihara anak tanpa didampingi oleh sosok Suami. Dalam kajian ini mengarahkan pemaknaan single mother secara umum yaitu setiap wanita yang ditinggal suami lantaran ditinggal mati, ditinggal cerai, ataupun ditinggalkan dalam tempo yang lama tanpa perhatian secara moril dan materil.

Adapun qashash Alqur'an merupakan satu sub kajian dalam disiplin ilmu Ulumul Qur'an. Di dalamnya dibahas tentang kisah-kisah yang diangkat Allah swt. dalam paparan ayat Alqur'an.Sa'ad Yusuf dalam buku qashash Alqur'an mengurai kurang-lebih 47 kisah yang dipaparkan Alqur'an. Mayoritas kisah yang diangkat oleh Alqur'an berkaitan dengan para Nabi dan Rasul. Namun, terdapat pula kisah-kisah lain yang berkaitan dengan sosok 
bukan dari kalangan Nabi namun memiliki kemuliaan dan keistimewaan tersendiri. Bahkan selain sosok yang dimuliakan juga menyentil kisah hidup orang-orang dzhalim di masanya semisal Fir'aun dan bala tentaranya.

Pesan-pesan Alqur'an dengan paparan kisah menjadi satu komponen isi. Ajakan ataupun larangan yang dipaparkan dengan kisah lebih mudah menyentuh perasaan pembaca ataupun yang mendengarkan, sehingga pesan-pesan dapat sampai dan diterima dengan lebih baik. Penggunaan kata qashash yang merupakan kata jamak dari qishshah berarti kisah, sempat menjadi sorotan. Apabila diperhatikan dalam kamus-kamus bahasa didapati kata qishash sebagai jamak dari qishshah (kamus online al-ma'ani). Dalam hal ini yang dipilih adalah qashash sesuai dengan bahasa Alqur'an dalam (QS. Al-A’raf \{7\}: 176).

\section{b. Tokoh single motherdalam kisah Alqur'an}

Kisah-kisah dalam Alqur'an berkisar 47-an dengan alur dan fase berbeda. Mayoritas kisah berkaitan dengan para Nabi dan Rasul terhadap kaumnya. Kisah-kisah tersebut merupakan gambaran yang mengandung pesan dan pembelajaran mendalam. Melewati penelusuran menyeluruh terhadap kisah-kisah tersebut secara global, didapati penggambaran tentang sosok single mother dalam kisah Alqur'an. Adapun profil dari masing-masing sosok single mother sebagai berikut :

\section{M aryam binti ‘'mran (I bu Nabi Isa as.)}

QS. Maryam $\{19\}$ :

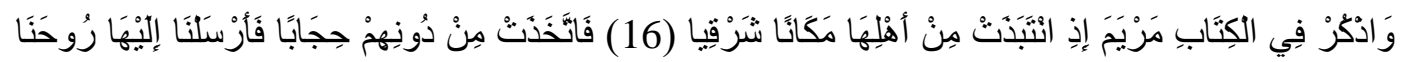

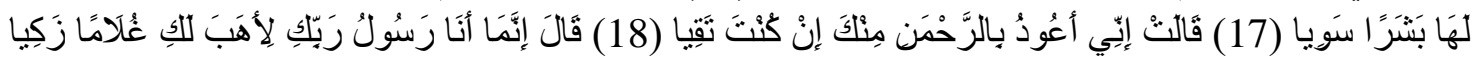

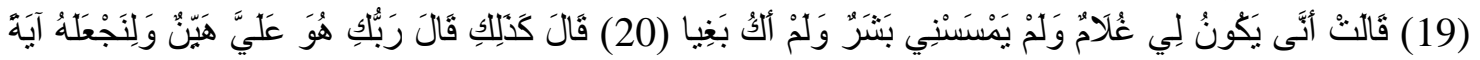

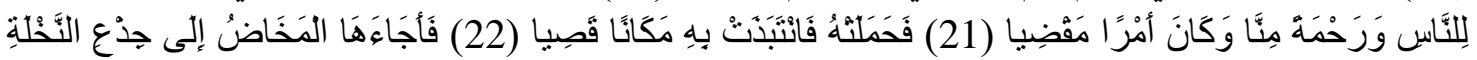

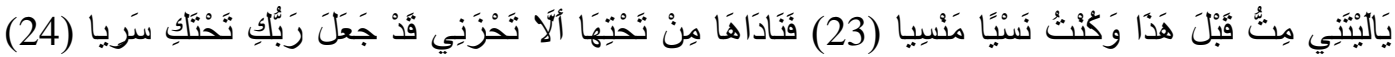

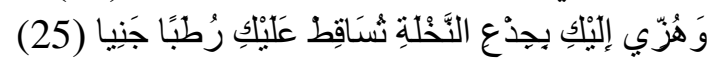

Terjemahnya : 16. Dan ceritakanlah (kisah) Maryam di dalam Al Quran, yaitu ketika ia menjauhkan diri dari keluarganya ke suatu tempat di sebelah timur, 17. maka ia mengadakan tabir (yang melindunginya) dari 
mereka; lalu Kami mengutus roh Kami (Jibril as.)kepadanya, maka ia menjelma di hadapannya (dalam bentuk) manusia yang sempurna. 18. Maryam berkata: "Sesungguhnya aku berlindung dari padamu kepada Tuhan Yang Maha pemurah, jika kamu seorang yang bertakwa." 19. Ia (jibril) berkata: "Sesungguhnya aku ini hanyalah seorang utusan Tuhanmu, untuk memberimu seorang anak laki-laki yang suci." 20. Maryam berkata: "Bagaimana akan ada bagiku seorang anak laki-laki, sedang tidak pernah seorang manusiapun menyentuhku dan aku bukan (pula) seorang pezina!" 21. Jibril berkata: "Demikianlah." Tuhanmu berfirman: "Hal itu adalah mudah bagiKu; dan agar dapat Kami menjadikannya suatu tanda bagi manusia dan sebagai rahmat dari Kami; dan hal itu adalah suatu perkara yang sudah diputuskan." 22. Maka Maryam mengandungnya, lalu ia menyisihkan diri dengan kandungannya itu ke tempat yang jauh. 23. Maka rasa sakit akan melahirkan anak memaksa ia (bersandar) pada pangkal pohon kurma, dia berkata: "Aduhai, alangkah baiknya aku mati sebelum ini, dan aku menjadi barang yang tidak berarti, lagi dilupakan." 24. Maka Jibril menyerunya dari tempat yang rendah: "Janganlah kamu bersedih hati, sesungguhnya Tuhanmu telah menjadikan anak sungai di bawahmu. 25. Dan goyanglah pangkal pohon kurma itu ke arahmu, niscaya pohon itu akan menggugurkan buah kurma yang masak kepadamu,

Maryam adalah putri dari seorang hamba Allah bernama 'Imran, yang namanya diabadikan dalam Alqur'an menjadi satu nama surah. Selain itu keluarganya disejajarkan dengan keluarga Ibrahim as.. Sepenggal kisah masyhur dalam Alqur'an berkaitan dengan seorang wanita (istri 'Imran) yang bernadzar agar anaknya kelak dapat menjadi penerus yang mengabdi di bait al-maqdis. Sebagaimana dipaparkan dalam QS. Ali 'Imran $\{3\}$ : 35.

Imran wafat sebelum kelahiran maryam. Sontak Ibunya, merasa sangat berat dengan cobaan tersebut, terlebih lagi ketika kelahiran maryam yang ternyata berjenis perempuan. Kekecewaan yang cukup mendalam lantaran kekhawatiran terhadap nadzar sang Ibu yang kemungkinannya sulit untuk tercapai. Pengabdian di baitul maqdis didominasi kaum pria, sedangkan maryam yang dicanangkan untuk pengabdian mulia 
itu adalah seorang perempuan. Hal itu tergambar dalam pengaduannya kepada Allah swt. sebagaimana tergambar dalam QS. Ali 'Imran $\{3\}: 36$

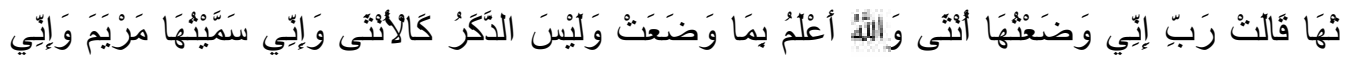

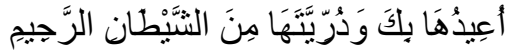

Terjemahnya : Maka tatkala isteri 'Imran melahirkan anaknya, diapun berkata: "Ya Tuhanku, sesunguhnya aku melahirkannya seorang anak perempuan; dan Allah lebih mengetahui apa yang dilahirkannya itu; dan anak laki-laki tidaklah seperti anak perempuan. Sesungguhnya aku telah menamai dia Maryam dan aku mohon perlindungan untuknya serta anak-anak keturunannya kepada (pemeliharaan) Engkau daripada syaitan yang terkutuk."

Setelah proses kelahiran, Ibu maryam tetap pada pendiriannya untuk menunaikan nazar yang telah diucapkannya bersama sang mendiang Suaminya. Menyerahkan anak tersebut untuk mengabdi pada bait al-maqdis, semata-mata menyembah dan menyerahkan hidup dalam pengabdian kepada Allah swt.. Jenis kelamin maryam yang terlahir sebagai wanita, sama sekali tidak mengurungkan niat sang Ibu. Maka dia-pun menunaikan nazar tersebut.

Nabi Zakariya as. yang kemudian dipercayakan untuk memeliharanya hingga dewasa. Nabi Zakariya as. adalah paman maryam, yang memiliki hubungan keluarga dengan ibu maryam melalui istri Nabi Zakariya. Beliau adalah seorang hamba Allah swt. yang kisahnya diabadikan pula dalam Alqur'an berkaitan seorang wanita mandul yang bersuamikan laki-laki tua,mereka seakan tidak mungkin lagi akan mendapatkan momongannamun ternyata berkat doa mereka yang dikabulkan oleh Allah swt. ternyata tiba-tiba mengandung. Kisah tersebut tercatat dengan jelas dalam QS. Ali 'Imran (3) : 38.

Paparan ayat-ayat di atas, memberikan informasi penting tentang status maryam sebagai single mother yang hakiki. Menjadi satu tanda kekuasaan Allah swt. Zat yang 
Mahapencipta, memberikan contoh betapa Allah swt. Mahakuasa atas segala sesuatu. Begitu mudah Allah swt. menciptakan Adam as. tanpa ada unsur pria dan wanita yang mendahuluinya. Kemudian menciptakan Hawwa dengan unsur pria tanpa ada wanita yang mendahului. Barulah pada maryam yang kemudian melahirkan Isa as., diperlihatkan oleh Allah swt. kelahiran manusia yang hanya didahului unsur wanita tanpa ada pria sebagai asalnya.

Maryam adalah potret orang tua tunggal sejati. Tidak pernah disentuh oleh lakilaki manapun, berdasarkan kehendak Allah swt. dia tiba-tiba hamil mengandung hamba pilihan Allah swt. yaitu Nabi Isa as.. Seluruh tahapan-tahapan berat dari beban tersebut kemudian dipikul sendiri oleh maryam. Tanpa ada jalan berbagi rasa dengan pasangan hidup laiknya manusia lain.

Pandangan miring, terhadap sosok terhadap seorang single motherbukanlah tanda akan kerendahan derajat seseorang. Kemuliaan seorang orang tua tunggal ditunjukkan Allah swt. dengan mengambil kisah single mother maryam sebagai bagian dari kesucian ayat-ayat Alqur'an.

Kisah yang ditonjolkan dalam Alqur'an berkaitan dengan posisi maryam sebagai single mother berkisar pada kehamilannya di luar kebiasaan, ketaatan dan kesucian maryam, kelahiran Isa as. dari rahim maryam, upaya maryam mengasuh dan membesarkan Isa meskipun dalam kondisi yang sangat terbatas.

\section{Ibu Nabi Musa as.}

QS. Al-Qashash :

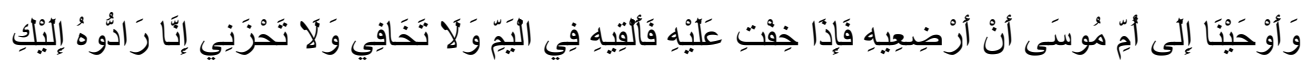

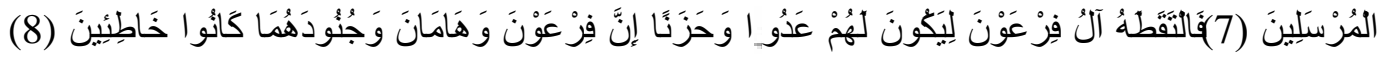

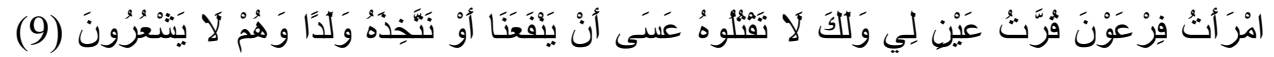

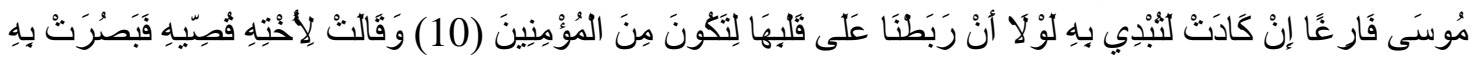




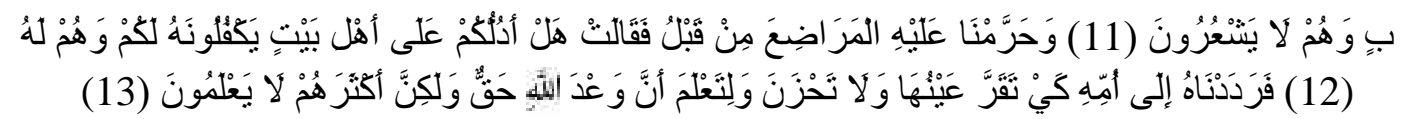

Terjemahnya : 7. Dan kami ilhamkan kepada ibu Musa; "Susuilah dia, dan apabila kamu khawatir terhadapnya maka jatuhkanlah dia ke sungai (Nil). Dan janganlah kamu khawatir dan janganlah (pula) bersedih hati, karena sesungguhnya Kami akan mengembalikannya kepadamu, dan menjadikannya (salah seorang) dari para rasul. 8. Maka dipungutlah ia oleh keluarga Fir'aun yang akibatnya dia menja- di musuh dan kesedihan bagi mereka. Sesungguhnya Fir'aun dan Ha- man beserta tentaranya adalah orang-orang yang bersalah. 9. Dan berkatalah isteri Fir'aun: "(Ia) adalah penyejuk mata hati bagiku dan bagimu. Janganlah kamu membunuhnya, mudah-mudahan ia bermanfaat kepada kita atau kita ambil ia menjadi anak", sedang mereka tiada menyadari. 10. Dan menjadi kosonglah hati ibu Musa. Sesungguhnya hampir saja ia menyatakan rahasia tentang Musa, seandainya tidak Kami teguhkan hati- nya, supaya ia termasuk orang-orang yang percaya (kepada janji Allah). 11. Dan berkatalah ibu Musa kepada saudara Musa yang perempuan: "Ikutilah dia" Maka kelihatanlah olehnya Musa dari jauh, sedang mereka tidak mengetahuinya, 12. dan Kami cegah Musa dari menyusu kepada perempuan-perempuan yang mau menyusui(nya) sebelum itu; maka berkatalah saudara Musa: "Maukah kamu aku tunjukkan kepadamu ahlul bait yang akan memeliharanya untukmu dan mereka dapat berlaku baik kepadanya?." 13. Maka kami kembalikan Musa kepada ibunya, supaya senang hatinya dan tidak berduka cita dan supaya ia mengetahui bahwa janji Allah itu adalah benar, tetapi kebanyakan manusia tidak mengetahuinya.

Satu lagi sosok wanita yang inisialnya diabadikan oleh Allah swt. dalam Alqur'an, dia adalah Ibu Nabi Musa as., dalam paparan mengenai kisah tentang Nabi Musa yang tersebar dalam beberapa lokasi dalam Alqur'an. Di dalamnya mengangkat secuplik kisah kekhawatiran seorang wanita yang baru saja melahirkan anak laki-laki, persis pada tahun dimana penguasa ketika itu (Fir'aun) membunuh setiap bayi laki-laki yang lahir.

Kisah tentang Ibu Nabi Musa as. dalam Alqur'an yang berjuang menyelamatkan jiwa anaknya dari kekejaman dan kedzaliman penguasa di kala itu yang 
akan membantai dan menghabisi seluruh bayi laki-laki yang lahir seantero mesir. Meskipun tidak ada referensi jelas mengenai keberadaan dan peran ayah Nabi Musa ketika itu, Alqur'an sama sekali luput menyinggung peran sang ayah. Hal ini menjadi indikasi utama penulis mengkategorikan Ibu Nabi Musa as. masuk dalam kategori single mother.

Muhammad Farid Wajdi dalam ensiklopedi Da'irat al-Ma'arif abad ke XX memuat silsilah Nabi Musa as. yang ternyata tersambung kepada Nabi Ibrahim as.. Adapun silsilahnya yaitu Musa bin 'Imran bin Qahat bin Lawy bin Ya'qub bin Ishaq bin Ibrahim. Ayah Nabi Musa ternyata bernama Imran namun dalam sederetan kisah tentang perjuangan Ibu Nabi Musa, nama tersebut sama sekali tidak muncul baik secara langsung maupun secara tersirat dengan kata ganti orang (dhamir).

Berkaitan dengan Ibu Nabi Musa as., Alqur'an memunculkan kisah tentang perjuangannya menjaga putranya agak terhindar dari jangkauan pengawal Fir'aun. Mulai dari petunjuk Allah untuknya mengalirkan Musa kecil pada sungai nil. Mengikuti petunjuk tersebut, mengalirkan bayinya di sungai nil benar-benar membuatnya khawatir dan takut akan keselamatan si bayi. Ternyata justru dipungut oleh Asiyahistri Fir'aun sendiri. Musa kecil dipelihara dalam keluarga Fir'aun hingga sang Ibu yang kemudian mendapatkan kesempatan untuk menyusukan anaknya secara langsung sebagaimana dalam QS. Al-Qashash $\{28\}$ : 8.

\section{Sitti Hajar (Ibu Nabi Ismail as.)}

QS. Ibrahim $\{14\}$ :

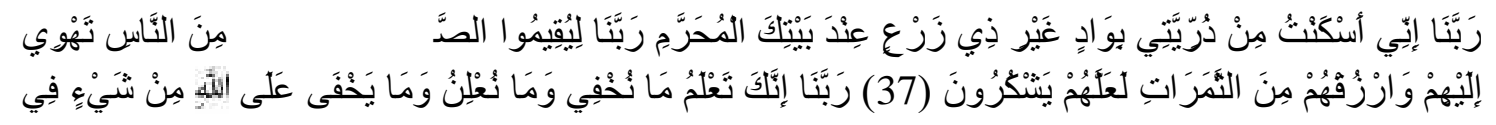

Terjemahnya : 37. Ya Tuhan kami, sesungguhnya aku telah menempatkan sebahagian keturunanku di lembah yang tidak mempunyai tanam- 
tanaman di dekat rumah Engkau (Baitullah) yang dihormati, ya Tuhan kami (yang demikian itu) agar mereka mendirikan shalat, maka jadikanlah hati sebagian manusia cenderung kepada mereka dan beri rezkilah mereka dari buah-buahan, mudah-mudahan mereka bersyukur. 38. Ya Tuhan kami, sesungguhnya Engkau mengetahui apa yang kami sembunyikan dan apa yang kami lahirkan; dan tidak ada sesuatupun yang tersembunyi bagi Allah, baik yang ada di bumi maupun yang ada di langit.

Hajar adalah sosok wanita yang diajukan oleh Sarah menjadi istri kedua Nabi Ibrahim as.. Keputusan besar diambil Sarah setelah sekian lama menjalani bahtera rumah tangga bersama Ibrahim as. dan ternyata belum juga beroleh keturunan. Sebagaimana dijelaskan dalam rangkaian sejarah, Sarah mengakui kondisi dirinya yang sulit mendapatkan momongan sehingga mengusulkan kepada suaminya Ibrahim as. untuk mengambil wanita lain sebagai alternatif lain selain dirinya, semoga dapat menghasilkan momongan yang diharapkan sebagai penerus.

Allah swt. ternyata benar-benar mengaruniakan Ismail as., melalui Sitti Hajar. Kebahagiaan di sisi Ibrahim as. dan Hajar dengan kelahiran Ismail merupakan anugerah yang dinantikan. Adapun di pihak Sarah, terjadi percabangan versi sejarah. Dalam kitab bidayah wa nihayah, Ibnu Katsir mengutip pendapat yang menjelaskan bahwa keberhasilan Hajar memberikan keturunan kepada Ibrahim membuatnya agak kurang nyaman. Sehingga mendorong Ibrahim as. membawa Hajar dan Ismail kecil menuju ke tempat lain yaitu Makkah. Adapun Sa'ad Yusuf mencoba menguraikan pendapat berbeda yang menonjolkan bahwa Ibrahim as. membawa Hajar dan Ismail menuju Makkah tanpa ada upaya kebencian ataupun dorongan dari Sarah melainkan sematamata menunaikan perintah Allah swt. (2004: 89).

Peran Hajar sebagai single mother kemudian bermula ketika Ibrahim as. meninggalkan mereka berdua di lembah gersang yang tidak berpenduduk. Ketika Ibrahim as. akan beranjak pergi meninggalkan mereka dengan bekal seadanya, Hajar 
sempat berusaha menanyakan mengapa Ibrahim tega meninggalkan istri dan bayinya yang masih sangat kecil di tempat semacam ini. Setelah Ibrahim memberi jawaban bahwa itu merupakan perintah Allah swt., dengan besar hati Hajar meyakinkan diri bahwa Allah swt. tidak akan menelantarkannya bersama Ismail.

Sungguh kisah perjuangan single mother yang luar biasa, mencari makan dan minum tanpa didampingi suami dan mencari tempat berlindung untuk berteduh di lembah yang tidak berpenghuni dengan beban memelihara anak yang masih bayi. Bukit shafa dan marwa yang belakangan kemudian dalam syari'at yang dibawa Rasulullah Muhammad saw. menjadi satu rangkaian Ibadah Haji dan Umrah adalah saksi sejarah kegigihan seorang Ibu bernama Hajar, bolak-balik berusaha mencari sumber air untuk minum bayinya Ismail kecil. Setelah mondar-mandir tanpa hasil sebanyak tujuh kali, dia berusaha menenangkan diri dan mendengarkan dengan seksama malaikat menghempaskan sayapnya ke tanah dan terpancarlah mata air zamzam persis di bawah kaki bayinya diletakkan.

\section{Dinamika hidup single mother}

\section{Rentan terhadap stigma buruk masyarakat}

Belajar dari kisah single mother yang diangkat Alqur'an, menunjukkan kerentanan bagi setiap single mother mendapatkan penilaian negatif atau stigma buruk terhadap pribadi dan keluarga mereka.

Maryam binti 'Imran, notabene merupakan anak dari seorang tokoh yang dikenal baik di masyarakatnya. Sejatinya, keturunannya-pun akan mendapatkan penilain yang sama baik oleh masyarakat yang mengenal sosok kedua orang tuanya. Namun, berkaitan dengan kejadian-kejadian yang terjadi kepadanya. Stigma negatif masih lebih dominan ditujukan kepadanya dibandingkan mendapat kesempatan membela diri ataupun memberikan sanggahan pembanding. Maka kemudian Allah swt. telah mengatur skenario yang dapat membungkam tuduhan-tuduhan tersebut dengan 
sebuah mu'jizat yang diberikan kepada Isa as. yang dapat berbicara meski masih dalam keadaan bayi yang baru lahir (QS. Ali 'Imran \{3\} : 46).

Kemuliaan maryam bukan hanya dari sisi orang tuanya, dia juga merupakan anak yang sejak kecilnya telah mengabdikan diri sebagai pelayan atau pembantu di tempat suci bait al-maqdis. Lebih dari itu, dia berada di bawah bimbingan dan arahan sang paman yaitu pemimpin para penghulu agama di bait al-maqdis Nabi Zakariya as.. berbeda dengan wanita lain di masanya, maryam telah tumbuh dalam lingkungan steril dari pergaulan buruk dan hanya menyibukkan diri dengan kegiatan peribadatan kepada Allah swt.. Namun itu semua tidak dapat menghalau perkiraan ataupun stigma buruk terhadap keanehan yang terjadi pada pribadi maryam binti 'Imran.

Dengan sangat mudah stigma negatif tentang kehamilannya menjadi polemik masyarakat di masanya, memaksa Nabi Zakariya as. mengisolasi maryam pada suatu mihrab yang tidak dapat diakses oleh siapapun. Sembari menunggu kelahiran sang bayi, maryam tetap pada ketetapan hati dan keimanan sempurna berpasrah kepada kehendak Allah swt.

\section{Terjepit dalam kondisi sekitar yang buruk}

Ibu Nabi Musa as., berada dalam kondisi yang sangat sulit. Pada dasarnya, tidak ada kesalahan yang diperbuat olehnya. Sangat lumrah ketika seorang Ibu mengandung dan melahirkan anak laki-laki. Namun pada masa kekuasaan Fir'aun, telah santer sebuah anggapan bahwa akan datang seorang dari keturunan Bani Israil yang akan mengalahkan penguasa mesir. Bukan sekedar anggapan belaka, kebenaran akan hal tersebut telah menjadi keyakinan yang disampaikan oleh penasihat raja Fir'aun kala itu. Sehingga mengusulkan untuk memotong cikal bakal kemunculan sosok yang tentu tidak diinginkan oleh Fir'aun selaku penguasa yang ingin melanggengkan kekuasaannya. Maka ditetapkanlah oleh Fir'aun untuk inspeksi rutin dan mengambil 
paksa setiap bayi laki-laki dari kalangan Bani Israil yang lahir lalu menghabisi nyawanya seketika itu juga. Persis Nabi Musa lahir pada tahun tersebut.

Ibu Nabi Musa yang notabene lemah tidak berdaya menghadapi kebijakan dzalim penguasa. Sejak dikandung, Musa telah mendapatkan perlindungan dari Allah swt. dengan perawakan Ibunya yang tidak menampakkan tanda-tanda kehamilan sama sekali. Proses melahirkannya pun berlangsung dengan senyap, tanpa mengundang kecurigaan pihak lain.

Setelah kelahiran Musa kecil, sang Ibu berusaha menyembunyikan semampunya. Hingga turun petunjuk dari Allah swt. kepadanya untuk mengalirkannya di sungai nil sesuai informasi QS. Al-Qashash $\{28\}$ : 7. Sebuah pilihan berat yang harus ditempuh, mengikuti petunjuk tersebut atau rela melihat putranya dibunuh oleh bala tentara Fir'aun.

\section{Memendam masalah dan menanggung beban sendiri}

Ibrahim as. dalam menjalankan perintah Allah swt., seringkali diuji dengan perintah yang sulit dicerna oleh akal manusia secara umum. Salah satu dari perintah tersebut adalah membawa bayi yang telah dinanti-nantikan olehnya bersama Istrinya untuk keluar meninggalkan bait al-maqdis. Membawa mereka ke wilayah yang sama sekali bukan destinasi kunjungan. Sebuah lembah yang tidak menunjukkan tanda-tanda kehidupan. Lebih beratnya semakin terasa, justru ketika Ibrahim as. meninggalkan istri dan anaknya pada tempat tersebut dengan bekal yang seadanya. Sungguh sebuah potret hamba yang beriman dan taat sepenuhnya kepada Allah swt..

Hajar sebagai seorang istri yang taat kepada suami dan beriman teguh kepada Allah swt., dengan mantap meyakini bahwa "Allah swt. tidak akan menyia-nyiakan kami di tempat ini”. Berikutnya mengambil sisi positif dari keadaan yang berat tersebut. Tanpa banyak protes kepada suami yang meninggalkannya, Hajar berusaha 
menerima kenyataan dan berusaha untuk tetap tegar menghadapi segala tantangan hidup berikutnya.

Perlahan-lahan, anugerah Allah swt.-pun nampak satu persatu. Mulai dengan munculnya mata air zamzam setelah upaya panjangnya bolak-balik mengitari dua bukit shafa dan marwa, menjadi secercah harapan keberlangsungan hidup. Beberapa waktu berselang keberadaan mereka di Makkah, datang satu qafilah yang berasal dari kalangan Jurhum yang kemudian meminta izin untuk menetap bersama Hajar dan Ismail kecil. Tanpa mengharap iba Hajar mempersilahkan mereka dengan syarat bahwa mata air zamzam tidak boleh diklaim oleh mereka.

Kegigihan dan ketetapan hati Hajar memelihara dan membesarkan buah hatinya seorang diri hingga Ismail tumbuh beranjak dewasa hingga beranak pinak di kota Makkah menjadi bukti kegigihan seorang single mother bernama Hajar yang tidak mengelukan permasalahannya kepada siapapun kecuali menyandarkan diri kepada Allah swt..

\section{Penutup}

Penelusuran yang telah dilakukan terhadap kisah-kisah yang mengangkat fenomena single mother ternyata dapat tercermin dari kisah tiga orang wanita mulia. Mereka adalah Maryam binti 'Imran Ibu Nabi Isa as. pada QS. Maryam \{19\} : 16-25., Ibu Nabi Musa as. pada QS. Al-Qashash $\{26\}$ : 7-13, dan Hajar Ibu Nabi Ismail as. pada QS. Ibrahim $\{14\}: 37-38$.

Elaborasi lebih dalam terhadap kisah-kisah tersebut selanjutnya dirumuskan menjadi sebuah dinamika hidup single mother yang sangat mungkin terjadi pada tiap kasus di setiap daerah. Potret yang diangkat Alqur'an hanyalah sebuah potret terbatas dari sederetan kesulitan-kesulitan hidup yang mungkin didapati oleh single mother dalam kehidupan masing-masing. Ragam dinamika hidup single mother yang dapat disarikan dari 
uraian kisah terangkum dalam tiga poin : pertama, rentan terhadap stigma buruk masyarakat; kedua, terjepit dalam kondisi sekitar yang buruk; dan ketiga, memendam masalah dan menanggung beban sendiri.

Sebuah simpulan sederhana pasca studi ini dipaparkan adalah sesungguhnya status single mother yang saat ini diemban ataupun dijalani oleh sekian banyak wanita di belahan bumi ini bukanlah sebuah aib yang patut diratapi secara berlebihan. Tantangan hidup akan senantiasa ada di depan mata, namun contoh sosok single mother yang disinggung oleh Allah swt. dalam Alqur'an adalah suri tauladan yang baik untuk kesuksesan dunia dan akhirat. Kegigihan dan ketabahan mereka menjalani keadaan tersebut justru menempatkan mereka sebagai wanita-wanita termulia dalam sejarah umat manusia.

Sebaliknya bagi pihak lain yang berada di sekitar single mother, mari kita ikut membantu dan memfasilitasi kesejahteraan mereka. Karena keterbatasan dan ketidakmampuan mereka akan terasa ringan dengan uluran tangan dari sesama.

\section{Daftar Pustaka}

Alqur'an al-Karim

Abu 'Aziz, Sa'ad Yusuf,Qashash Alqur'an (Durus wa 'Ibar), Cet. II (Cairo; Dar al-Fajr li al-turats, 2004)

Ibn Katsir, Al-Hafidz 'Imad al-Din Abi al-Fida' Isma'il Ibn Umar, Tahqiq 'Abdullah ibn 'Abd al-Muhsin al-Turki, al-Bidayah wa al-Nihayah, Juz I (t.t; Dar al-Hijr, t.th)

Shihab, M. Quraish, Tafsir al-Misbah : pesan, dan keserasian Al-Qur'an, Edisi revisi Cet. I, Juz 2 (Tangerang: PT. Lentera Hati, 2016).

Terjemah Alqur'an Digital

Wajdi, Muhammad Farid,Da'irat al-Ma'arif al-qarn al-'Isyrun,Cet. III, Juz VIII (Beirut Libanon; Dar al-Fikr, 1971) 